\title{
Short communication: The effect of substituting fish oil in dairy cow diets with docosahexaenoic acid-micro algae on milk composition and fatty acids profile
}

\author{
A. A. AbuGhazaleh, ${ }^{* 1}$ R. B. Potu, ${ }^{*}$ and S. Ibrahim $†$ \\ *Department of Animal Science, Food and Nutrition, Southern Illinois University, Carbondale 62901 \\ †Food and Nutritional Sciences Program, North Carolina A\&T State University, Greensboro 27411
}

\begin{abstract}
The effects of substituting fish oil (FO) with docosahexaenoic acid (DHA)-micro algae on milk chemical and fatty acid composition were examined in this study. Twenty-four Holstein cows in mid lactation grazing on an alfalfa-grass based pasture were divided into 4 treatment groups (6 cows/treatment) and supplemented with $7 \mathrm{~kg} / \mathrm{d}$ grain mix plus $350 \mathrm{~g}$ of soybean oil and one of the following: 1) $150 \mathrm{~g}$ of FO, 2) $100 \mathrm{~g}$ of FO plus $50 \mathrm{~g}$ of algae, 3) $50 \mathrm{~g}$ of FO plus $100 \mathrm{~g}$ of algae, or 4) $150 \mathrm{~g}$ of algae. Cows were fed treatment diets for $3 \mathrm{wk}$, and milk samples were collected from each cow during the last $3 \mathrm{~d}$ of the study. Milk production $(17.96,17.56,17.55$, and $19.26 \mathrm{~kg} / \mathrm{d}$ for treatment diets 1 to 4 , respectively), milk fat percentages $(3.17,3.49$, 3.74 , and $3.43 \%$ ), and milk protein percentages (3.35, $3.50,3.71$, and $3.42 \%$ ) were similar between treatment diets. Concentrations (g/100 g of fatty acids) of milk cis-9 trans-11 (c9t11) conjugated linoleic acid (CLA; $3.41,3.69,4.47$, and 4.21 for treatment diets 1 to 4 , respectively) and vaccenic acid (11.80, 12.83, 13.87, and 13.53) were similar between treatment diets. Results of this study suggest that DHA-micro algae can partially or fully substitute FO in a cow's diet without any adverse effects on milk production, milk composition, or milk $c 9 t 11$ CLA content. The DHA-micro algae may be used as a viable alternative for FO in cow's diet to modify rumen biohydrogenation to increase milk $c 9 t 11$ CLA content.
\end{abstract}

Key words: fish oil, micro-algae, milk composition, cis-9 trans-11 conjugated linoleic acid

Fish oil (FO) in dairy cow diets has been shown to function as a modifier of ruminal biohydrogenation of dietary unsaturated fatty acids (FA), resulting in increased milk fat conjugated linoleic acid (CLA) content, and cis-9 trans-11 (c9t11) CLA in particular

Received May 19, 2009.

Accepted September 20, 2009.

${ }^{1}$ Corresponding author: aabugha@siu.edu
(Donovan et al., 2000; Loor et al., 2005; Rego et al., 2005). The stimulatory effect of FO on milk c9t11 CLA has been attributed to its ability to inhibit the reduction of trans C18:1 to C18:0 in the rumen, which is largely responsible for an increase in the supply of vaccenic acid (VA; $t 11$ C18:1), the primary precursor for $c 9 t 11$ CLA synthesis in the mammary gland via $\Delta^{9}$-desaturase (Griinari et al., 2000; Mosley et al., 2006). The ability of FO to promote VA accumulation in the rumen has been attributed largely to its docosahexaenoic acid (DHA; C22:6n-3) content (AbuGhazaleh and Jenkins, 2004).

Because of the drastic increase in FO demand (Tacon, 2004) and recent evidence of a plateau in fishery yields that provide the world's supply of marine feedstuffs (Pauly et al., 2002), alternatives to FO are being sought. Recent developments in algal and fungal culture may provide alternatives to FO as sources of DHA. Currently, different micro algae products high in DHA are produced commercially for both human and animal food/feed industries. Therefore, the objectives of this study were to evaluate the effects of substituting FO with DHA-micro algae on animal performance and milk chemical and FA composition and to investigate whether DHA-micro algae show a similar inhibition effect on rumen biohydrogenation as has been observed with FO.

All procedures for this trial were approved by the Southern Illinois University Intuitional Animal Care and Use Committee. Cows were selected from the Southern Illinois University Carbondale Dairy Research Center. Two weeks before the start of the study, 24 multiparous Holstein cows were allowed to graze on a pasture consisting of alfalfa, orchardgrass, fescue, and weeds (40:30:20:10 wt/wt). Pasture chemical composition (DM basis) averaged 15.6\% CP, 31.6\% ADF, $53.9 \%$ NDF, and $2.7 \%$ ether extract. Palmitic, linoleic, and linolenic acids were the 3 main FA in pasture, accounting for 16.4, 14.1, and $42.3 \%$ of total FA, respectively. Cows were supplemented with $7 \mathrm{~kg} / \mathrm{d}$ of a grain mix supplement consisting of cracked corn $(49.0 \%)$, soybean meal $(29.4 \%)$, dried molasses $(10.44 \%)$, meat and bone meal (4.20\%), and mineral and vitamin mix (6.96\%). 
Milk production was recorded daily, and milk samples were collected from each cow during the last $3 \mathrm{~d}(0600$ and $1800 \mathrm{~h}$ ) of wk 2 for composition and FA analysis. Milk production and composition data generated during these $2 \mathrm{wk}$ were used for covariance analysis. At the start of wk 3, cows were allotted to treatment (6 cows/treatment) according to their milk yield (21.4 \pm $3.6 \mathrm{~kg} / \mathrm{d})$ and DIM $(205 \pm 35)$ and received the same grain supplement $(7 \mathrm{~kg} / \mathrm{d})$ plus $350 \mathrm{~g}$ soybean oil and one of the following: 1) $150 \mathrm{~g}$ of FO, 2) $100 \mathrm{~g}$ of FO plus $50 \mathrm{~g}$ of algae, 3) $50 \mathrm{~g}$ of FO plus $100 \mathrm{~g}$ of algae, or 4) $150 \mathrm{~g}$ of algae. Cows were fed the treatment diets for $21 \mathrm{~d}$ and continued to graze the same pasture. All cows were grazed together under intensive rotational grazing management. The pasture area was 21 acres and was divided into 21 one-acre paddocks, yielding approximately $170 \mathrm{~m}^{2}$ of pasture area per cow per day. All cows were moved to a new paddock every morning to ensure enough pasture allowance. Polywire fencing prevented cows from grazing the next paddock or the previous grazed areas. Cows remained on the pasture daily for about $21 \mathrm{~h}$ and had free access to water. The pasture was fertilized with ammonium nitrate at a rate of $20 \mathrm{~kg}$ of N/acre. Menhaden FO (Omega Protein Inc., Hammond, LA; DHA = $11.5 \mathrm{~g} / 100 \mathrm{~g}$ of FA) and S-type Gold Algae (Martek Inc., Baltimore, MD; DHA = 162 $\mathrm{g} / \mathrm{kg}$ of DM) were used in this study. Soybean oil, algae, and $\mathrm{FO}$ were stored at $5^{\circ} \mathrm{C}$ and mixed with the grain supplement every morning before feedings. The grain supplement was offered in 2 equal portions after the morning and afternoon milkings using Calan Broadbent feeder doors (American Calan Inc., Northwood, NH).

Cows were milked daily at 0600 and $1800 \mathrm{~h}$ and milk yield was recorded for each milking. Milk samples were collected at 6 consecutive milkings (p.m. and a.m.) on the last $3 \mathrm{~d}$ of the study. Twenty-four-hour composites of each cow's milk, with amounts proportional to milk yield at each time, were divided into 2 portions for analysis. One portion was refrigerated at $4^{\circ} \mathrm{C}$ and sent to a laboratory for chemical analysis; the other portion of each sample was stored at $-20^{\circ} \mathrm{C}$ until analysis for fatty acid composition. Milk samples were analyzed for chemical and FA composition as outlined by AbuGhazaleh and Holmes (2007).

Data were analyzed using the MIXED procedure of SAS (SAS Institute, Cary, NC) for a complete randomized design. The statistical model was $y_{i j k}=\mu+D_{i}$ $+T_{j}+C_{k}+e_{i j k}$, where $y_{i j k}$ is the observation, $\mu$ the overall mean, $D_{i}$ is the FA treatment, $T_{j}$ is the day, $C_{k}$ the covariance effect, and $e_{i j k}$ is the residual error. The random effect was cow within FA treatment. Least squares means (adjusted for the covariance) are reported throughout; $P<0.05$ was selected to represent level of significance.
Previous research showed that feeding FO to dairy cows at 120 to $150 \mathrm{~g} / \mathrm{d}$ along with plant oils maximized ruminal VA production and resultant yields of $c 9 t 11$ CLA in milk fat (Palmquist and Griinari, 2006; Whitlock et al., 2006; Cruz-Hernandez et al., 2007). In the current study, partial or total substitution of FO with algae had no significant effect $(P>0.05)$ on milk yield $(17.96,17.56,17.55$, and $19.26 \mathrm{~kg} / \mathrm{d}$ for treatment diets 1 to 4 , respectively), milk fat percentages $(3.17,3.49$, 3.74 , and $3.43 \%)$, milk fat yields $(0.57,0.59,0.61$, and $0.65 \mathrm{~kg} / \mathrm{d})$, milk protein percentages $(3.35,3.50,3.71$, and $3.42 \%)$, or milk protein yields $(0.59,0.60,0.62$, and $0.64 \mathrm{~kg} / \mathrm{d}$ ) (Table 1). Compared with pretrial levels, milk fat content was reduced by approximately $26 \%$ $(4.67$ vs. $3.46 \%)$ with oil and algae supplementation. Supplementing diets with oils rich in polyunsaturated FA or algae generally causes a reduction in milk fat content (Donovan et al., 2000; Whitlock et al., 2006; Boeckaert et al., 2008). The grain supplement intake averaged $7.26,7.41,7.42$, and $7.32 \mathrm{~kg} / \mathrm{d}$ for treatment diets 1 to 4 , respectively.

With the exception of $\mathrm{C} 14: 0$, t6/8 C18:1, t9 C18:1, and $c 9$ C18:1, substituting FO with algae had no effect $(P>0.05)$ on milk FA composition (Table 2). The concentrations of the sum of the even-chain C4:0 to C14:0 were similar $(P>0.05)$ among treatment diets, averaging $10.03,9.98,11.87$, and $10.70 \mathrm{~g} / 100 \mathrm{~g}$ of FA for treatment diets 1 to 4 , respectively. Compared with the pretrial level, the percentage of $\mathrm{C} 4: 0$ to $\mathrm{C} 14: 0$ were reduced by approximately $19 \%$ (13.12 vs. $10.64 \%)$ with oil and algae supplementations. The decrease in the proportion of short- and medium-chain FA (C4:0 to C14:0) with oil and algae supplementation is in agreement with others (Donovan et al., 2000; Whitlock et al., 2006; Boeckaert et al., 2008; Brown et al., 2008) who reported similar reductions in de novo FA synthesis in cows fed oil and or algae, which is probably attributed to greater intake of polyunsaturated FA. The polyunsaturated FA, their biohydrogenation products, or both are potent inhibitors of mammary synthesis of shortand medium-chain FA through a direct inhibitory effect on acetyl-CoA carboxylase activity (Baumgard et al., 2002; Bauman and Griinari, 2003).

The main objective of this study was to evaluate the effects of substituting FO with DHA-micro algae on milk VA and $c 9 t 11$ CLA. Partial or total substitution of FO with algae had no effect $(P>0.05)$ on milk concentrations of VA $(11.80,12.83,13.87$, and $13.53 \mathrm{~g} / 100$ $\mathrm{g}$ of FA for treatment diets 1 to 4 , respectively) and $c 9 t 11$ CLA $(3.41,3.69,4.47$, and $4.21 \mathrm{~g} / 100 \mathrm{~g}$ of FA). Compared with pretrial levels, milk VA and $c 9 t 11$ CLA increased by approximately 3.2-fold (3.12 vs. $13.09 \%$ ) and 3.4-fold (0.91 vs. 3.97\%), respectively, consistent with earlier studies reporting increases in milk VA and 
Table 1. Effect of treatment diets on milk yield, milk composition, BW, and BCS

\begin{tabular}{|c|c|c|c|c|c|c|c|c|}
\hline Item & \multicolumn{4}{|c|}{ Treatment $^{1}$} & SEM & \multicolumn{3}{|c|}{ Contrast $^{2}(P$-value $)$} \\
\hline Milk, kg/d & 17.96 & 17.56 & 17.55 & 19.26 & 1.089 & 0.43 & 0.34 & 0.89 \\
\hline$\%$ & 3.17 & 3.49 & 3.74 & 3.43 & 0.249 & 0.35 & 0.22 & 0.19 \\
\hline $\mathrm{kg} / \mathrm{d}$ & 0.57 & 0.59 & 0.61 & 0.65 & 0.045 & 0.19 & 0.91 & 0.32 \\
\hline \multicolumn{9}{|l|}{ Protein } \\
\hline Total solids, $\%$ & 11.96 & 12.46 & 12.87 & 12.40 & 0.280 & 0.17 & 0.09 & 0.06 \\
\hline MUN, \% & 12.28 & 10.07 & 10.98 & 12.61 & 1.122 & 0.69 & 0.09 & 0.36 \\
\hline $\mathrm{SCC}, \times 10^{3} / \mathrm{mL}$ & 110.27 & 81.96 & 214.23 & 108.46 & 43.347 & 0.52 & 0.35 & 0.63 \\
\hline $\mathrm{BW}, \mathrm{kg}$ & 650 & 635 & 609 & 622 & 42 & 0.85 & 0.69 & 0.47 \\
\hline $\mathrm{BCS}^{3}$ & 3.20 & 3.15 & 3.30 & 3.20 & 0.150 & 0.71 & 0.66 & 0.58 \\
\hline
\end{tabular}

${ }^{1} \mathrm{FO}=150 \mathrm{~g}$ fish oil $(\mathrm{FO})$ per day; $2 / 3 \mathrm{FO}=100 \mathrm{~g}$ of $\mathrm{FO}+50 \mathrm{~g}$ of algae per day; $1 / 3 \mathrm{FO}=50 \mathrm{~g}$ of $\mathrm{FO}+100 \mathrm{~g}$ of algae per day; ALG = 150 g of algae per day.

${ }^{2}$ Lin $=$ linear effect; Quad $=$ quadratic effect.

${ }^{3}$ Scored on a 5 -point scale, where $1=$ emaciated to $5=$ overly fat.

$c 9 t 11$ CLA concentrations when feeding oils and algae to dairy cows (Franklin et al., 1999; Donovan et al., 2000; Whitlock et al., 2006: Boeckaert et al., 2008; Brown et al., 2008). Although not significant, milk VA and $c 9 t 11$ CLA concentrations tended to increase linearly $(P<$ 0.09), whereas milk C18:0 tended to decrease linearly
$(P<0.06)$ in the diets with greater substitution of algae, indicating that algae exerted more inhibitory effects than FO in the final biohydrogenation step in the rumen. A stronger inhibition in the reduction step of VA to C18:0 leads to more substrate in the mammary glands for $\Delta^{9}$-desaturase activity to synthesize

Table 2. Effect of treatment diets on milk fatty acid (FA) composition (g/100 g FA)

\begin{tabular}{|c|c|c|c|c|c|c|c|c|}
\hline \multirow[b]{2}{*}{ Item } & \multicolumn{4}{|c|}{ Treatment $^{1}$} & \multirow[b]{2}{*}{ SEM } & \multicolumn{3}{|c|}{ Contrast $^{2}(P$-value $)$} \\
\hline & $\mathrm{FO}$ & $2 / 3 \mathrm{FO}$ & $1 / 3 \mathrm{FO}$ & ALG & & Lin & Quad & FO vs. ALG \\
\hline $\mathrm{C} 4: 0$ & 1.07 & 0.99 & 1.12 & 0.99 & 0.136 & 0.87 & 0.85 & 0.83 \\
\hline C6:0 & 0.83 & 0.90 & 1.03 & 0.86 & 0.087 & 0.58 & 0.17 & 0.33 \\
\hline $\mathrm{C} 8: 0$ & 0.40 & 0.49 & 0.60 & 0.43 & 0.047 & 0.39 & 0.01 & 0.07 \\
\hline C10:0 & 0.81 & 0.96 & 1.10 & 0.85 & 0.084 & 0.53 & 0.03 & 0.11 \\
\hline C12:0 & 1.12 & 1.29 & 1.45 & 1.18 & 0.095 & 0.43 & 0.03 & 0.10 \\
\hline C14:0 & 5.80 & 6.44 & 6.89 & 6.41 & 0.321 & 0.12 & 0.09 & 0.04 \\
\hline C4:0-14:0 & 10.03 & 9.98 & 11.87 & 10.70 & 0.829 & 0.30 & 0.51 & 0.40 \\
\hline C16:0 & 24.01 & 23.88 & 23.97 & 23.86 & 0.537 & 0.88 & 0.99 & 0.86 \\
\hline C18:0 & 9.20 & 8.75 & 7.32 & 6.85 & 0.836 & 0.06 & 0.36 & 0.08 \\
\hline \multicolumn{9}{|l|}{ trans $\mathrm{C} 18: 1$} \\
\hline trans-6/8 & 0.74 & 0.78 & 0.89 & 0.92 & 0.070 & 0.05 & 0.97 & 0.04 \\
\hline trans-9 & 0.87 & 1.00 & 1.09 & 1.12 & 0.054 & 0.00 & 0.32 & 0.00 \\
\hline trans-10 & 1.65 & 1.82 & 1.45 & 1.39 & 0.250 & 0.45 & 0.61 & 0.31 \\
\hline trans-11 & 11.80 & 12.83 & 13.87 & 13.53 & 0.779 & 0.09 & 0.39 & 0.09 \\
\hline trans-12 & 1.14 & 1.31 & 1.37 & 1.37 & 0.107 & 0.13 & 0.42 & 0.10 \\
\hline trans-16 & 0.60 & 0.59 & 0.53 & 0.78 & 0.056 & 0.07 & 0.03 & 0.63 \\
\hline C18:1 cis -9 & 22.60 & 21.23 & 18.59 & 19.84 & 1.285 & 0.08 & 0.09 & 0.03 \\
\hline C18:2n-6 & 1.53 & 1.50 & 1.62 & 1.77 & 0.125 & 0.13 & 0.48 & 0.47 \\
\hline C18:3n-3 & 0.35 & 0.31 & 0.35 & 0.29 & 0.026 & 0.18 & 0.65 & 0.23 \\
\hline CLA, cis-9 trans-11 & 3.41 & 3.69 & 4.47 & 4.21 & 0.464 & 0.08 & 0.64 & 0.10 \\
\hline CLA, cis-9 cis-11 & 0.02 & 0.00 & 0.02 & 0.01 & 0.005 & 0.54 & 0.42 & 0.16 \\
\hline CLA, trans -9 trans -11 & 0.24 & 0.15 & 0.42 & 0.26 & 0.055 & 0.18 & 0.52 & 0.57 \\
\hline C20:5n-3 & 0.04 & 0.03 & 0.04 & 0.04 & 0.009 & 0.58 & 0.96 & 0.92 \\
\hline $\mathrm{C} 22: 6 \mathrm{n}-3\left(\mathrm{DHA}^{3}\right)$ & 0.03 & 0.04 & 0.06 & 0.05 & 0.014 & 0.18 & 0.70 & 0.29 \\
\hline
\end{tabular}

${ }^{1} \mathrm{FO}=150 \mathrm{~g}$ fish oil $(\mathrm{FO})$ per day; $2 / 3 \mathrm{FO}=100 \mathrm{~g}$ of $\mathrm{FO}+50 \mathrm{~g}$ of algae per day; $1 / 3 \mathrm{FO}=50 \mathrm{~g}$ of $\mathrm{FO}+100 \mathrm{~g}$ of algae per day; ALG $=150$ $\mathrm{g}$ of algae per day.

${ }^{2}$ Lin $=$ linear effect; Quad $=$ quadratic effect.

${ }^{3} \mathrm{DHA}=$ docosahexaenoic acid. 
$c 9 t 11$ CLA. The apparent greater potency for algae to inhibit VA reduction to C18:0 may have resulted from cows consuming more DHA, because the micro-algae contained more DHA than did the FO. Incremental increases in DHA addition to rumen cultures results in a dose-dependent accumulation for trans C18:1 (Boeckaert et al., 2007). These results further confirm our previous observation (AbuGhazaleh and Jenkins, 2004) that DHA is the active component in FO that promotes the incomplete biohydrogenation and VA accumulation. No significant differences $(P>0.05)$ among treatment diets for C11:0, C14:1, C15:0, C16:1, C17:0, C17:1, $c 11$ C18:1, and C22:5 were observed in this study (data not reported). In conclusion, our results showed that cows receiving partial or full substitution of micro-algae had similar milk yield and composition to cows receiving FO supplementation. Thus, DHA-micro algae may replace FO in dairy cow diets as a modifier for rumen biohydrogenation to increase milk $c 9 t 11$ CLA content.

\section{REFERENCES}

AbuGhazaleh, A. A., and L. D. Holmes. 2007. Diet supplementation with fish oil and sunflower oil to increase conjugated linoleic acid levels in milk fat of partially grazing dairy cows. J. Dairy Sci. 90:2897-2904.

AbuGhazaleh, A. A., and T. C. Jenkins. 2004. Short communication: Docosahexaenoic acid promotes vaccenic acid accumulation in mixed ruminal cultures when incubated with linoleic acid. J. Dairy Sci. 87:1047-1050.

Bauman, D. E., and J. M. Griinari. 2003. Nutritional regulation of milk fat synthesis. Annu. Rev. Nutr. 23:203-227.

Baumgard, L. H., W. J. Weber, G. W. Kazmer, S. A. Zinn, L. B. Hansen, H. Chester-Jones, and B. A. Crooker. 2002. Trans-10, cis-12 conjugated linoleic acids decreases lipogenic rates and expression of genes involved in milk lipid synthesis in dairy cows. J. Dairy Sci. 85:2155-2163.

Boeckaert, C., B. Vlaeminck, J. Dijkstra, A. Issa-Zacharia, T. Van Nespen, W. Van Straalen, and V. Fievez. 2008. Effect of dietary starch or micro algae supplementation on rumen fermentation and milk fatty acid composition of dairy cows. J. Dairy Sci. 91:47144727 .

Boeckaert, C., B. Vlaeminck, J. Mestdagh, and V. Fievez. 2007. In vitro examination of DHA-edible micro algae 1. Effect on rumen lipolysis an biohydrogenation of linoleic and linolenic acids. Anim. Feed Sci. Technol. 136:63-79.

Brown, W., A. A. AbuGhazaleh, and S. Ibrahim. 2008. Milk conjugated linoleic acid response to fish oil and linseed oil supplementation to grazing dairy cows. Asian-australas. J. Anim. Sci. 21:663-670.

Cruz-Hernandez, C., J. K. G. Kramer, J. J. Kennelly, D. R. Glimm, B. M. Sorensen, E. K. Okine, L. A. Goonewardene, and R. J. Weselake. 2007. Evaluating the conjugated linoleic acid and trans 18:1 isomers in milk fat of dairy cows fed increasing amounts of sunflower oil and a constant level of fish oil. J. Dairy Sci. 90:3786-3801.

Donovan, D. C., D. J. Schingoethe, R. J. Baer, J. Ryali, A. R. Hippen, and S. T. Franklin. 2000. Influence of dietary fish oil on conjugated linoleic acid and other fatty acids in milk from lactating dairy cows. J. Dairy Sci. 83:2620-2628.

Franklin, S. T., K. R. Martin, R. J. Baer, and D. J. Schingoethe. 1999. Dietary marine algae (Schizochytrium sp.) increase concentrations of conjugated linoleic acid, conjugated linoleic acid, docosahexanoic acid, and trans-vaccenic acid of milk in dairy cow. J. Nutr. 129:2048-2052.

Griinari, J. M., B. A. Corl, S. H. Lacy, P. Y. Chouinard, K. V. V. Nurmela, and D. E. Bauman. 2000. Conjugated linoleic acid is synthesized endogenously in lactating dairy cows by $\Delta 9$ desaturase. J. Nutr. 130:2285-2291.

Loor, J. J., M. Doreau, J. M. Chardigny, A. Ollier, J. L. Sebedio, and Y. Chilliard. 2005. Effects of ruminal or duodenal supply of fish oil on milk fat secretion and profiles of trans-fatty acids and conjugated linoleic acid isomers in dairy cows fed maize silage. Anim. Feed Sci. Technol. 119:227-246.

Mosley, E. E., B. Shafii, P. J. Moate, and M. A. McGuire. 2006. Cis9, trans-11 conjugated linoleic acid is synthesized directly from vaccenic acid in lactating dairy cattle. J. Nutr. 136:570-575.

Palmquist, D. L., and J. M. Griinari. 2006. Milk fatty acid composition in response to reciprocal combinations of sunflower and fish oils in the diet. Anim. Feed Sci. Technol. 131:358-369.

Pauly, D., V. Christensen, S. Guienette, T. J. Pitcher, U. R. Sumaila, C. J. Walters, R. Watson, and D. Zeller. 2002. Towards sustainability in world fisheries. Nature 418:689-695.

Rego, O. A., H. J. D. Rosa, P. V. Portugal, R. Cordeiro, A. E. S. Borba, C. M. Vauzela, and R. J. B. Bessa. 2005. Influence of dietary fish oil on conjugated linoleic acid, omega-3 and other fatty acids in milk fat from grazing dairy cows. Livest. Prod. Sci. 95:27-33.

Tacon, A. G. J. 2004. Use of fish meal and fish oil in aquaculture: A global perspective. Aquatic Resour. Cult. Dev. 1:3-14.

Whitlock, L. A., D. J. Schingoethe, A. A. AbuGhazaleh, A. R. Hippen, and K. R. Kalscheur. 2006. Milk production and composition from cows fed small amounts of fish oil and extruded soybeans. J. Dairy Sci. 89:3972-3980. 